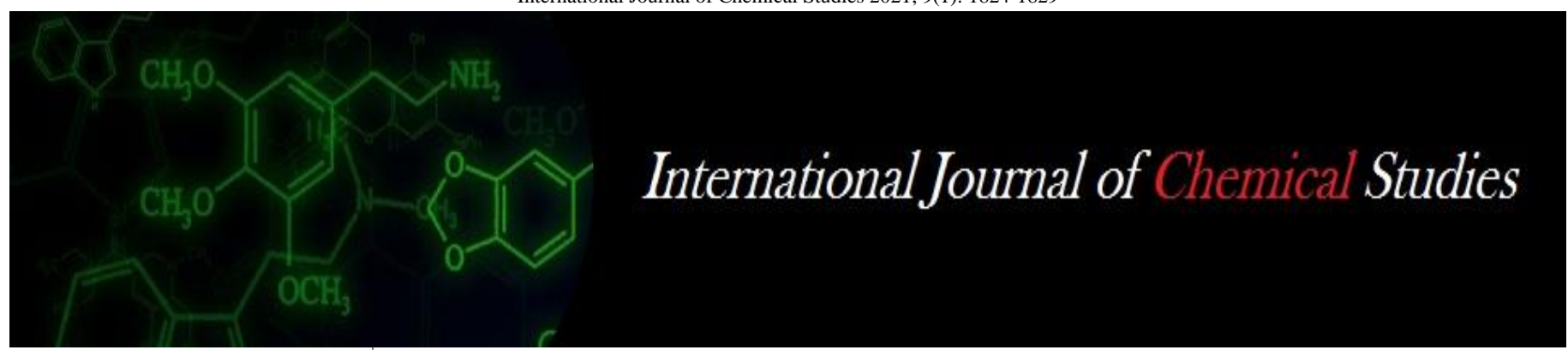

P-ISSN: 2349-8528

E-ISSN: 2321-4902

www.chemijournal.com

IJCS 2021; 9(1): 1824-1829

(C) 2021 IJCS

Received: 04-11-2020

Accepted: 13-12-2020

Navin Kumar Ranjan

Department of Horticulture,

Birsa Agricultural University,

Kanke, Ranchi, Jharkhand,

India

\section{S Sengupta}

Department of Horticulture,

Birsa Agricultural University,

Kanke, Ranchi, Jharkhand,

India

\section{AK Tiwary}

Department of Horticulture, Birsa Agricultural University, Kanke, Ranchi, Jharkhand, India

\section{Suresh Chandra Gurjar}

Department of Horticulture,

Birsa Agricultural University,

Kanke, Ranchi, Jharkhand,

India

\section{Usha Kumari}

Department of Horticulture,

Birsa Agricultural University, Kanke, Ranchi, Jharkhand,

India

Nirmala Kumari

Department of Soil Science and Agricultural Chemistry, PalliSiksha Bhavana, Institute of Agriculture Visva-Bharati, Sriniketan, West Bengal, India

\section{Corresponding Author:} Navin Kumar Ranjan Department of Horticulture, Birsa Agricultural University, Kanke, Ranchi, Jharkhand, India

\section{Effect of plant growth regulators on yield attributes of taro [Colocasia esculenta var. antiquorum (L.) schott.]}

\author{
Navin Kumar Ranjan, S Sengupta, AK Tiwary, Suresh Chandra Gurjar, \\ Usha Kumari and Nirmala Kumari
}

DOI: $\underline{\text { htps://doi.org/10.22271/chemi.2021.v9.i1z.11488 }}$

\begin{abstract}
Colocasia [Colocasia esculenta var. antiquorum (L.) schott.], which is also known as Taro, Arvi, Katchu and eddode belongs to the family Araceae is an important edible aroid. Africa ranks first in area and production of colocasia and in India colocasia is favourite among Gujarat, Konkan region of Maharashtra and several other parts of south India. The cormels, corms, leaves and petioles are used as a vegetable and considered as rich source of carbohydrates, proteins, minerals and vitamins. Due to increasing demand of taro, there is a need to increase its yield. Foliar application of plant growth regulators is reported to improve growth and tuber yield. Hence, the present investigation has been carried out in the the Horticulture Research unit, Department of Horticulture, Faculty of Agriculture, Birsa Agricultural University, Kanke, Ranchi during Kharif season of 2017. There were eleven treatments used namely $\mathrm{T}_{1}$ Naphthalene Acetic Acid (25 ppm), T2- Naphthalene Acetic Acid (50 ppm), T3- Indole Acetic Acid (25 ppm), $\mathrm{T}_{4-}$ Indole Acetic Acid (50 ppm), T5- Maleic Hydrazide $(50 \mathrm{ppm}), \mathrm{T}_{6}-$ Maleic Hydrazide (100 ppm), $\mathrm{T}_{7}$ - Gibberellic Acid (100 ppm), $\mathrm{T}_{8}$ - Gibberellic Acid (200 ppm), $\mathrm{T}_{9}$ - Ethrel (75 ppm), $\mathrm{T}_{10}$ - Ethrel $(150 \mathrm{ppm})$ and $\mathrm{T}_{11^{-}}$Control (water spray only). To find out feasibility of increment in growth \& yield of taro by means of application of plant growth regulators on the till date most accepted variety of taro, Muktakeshi by the growers in the state of Jharkhand. Among the eleven treatments used $\mathrm{GA}_{3}$ at $200 \mathrm{ppm}$ was found to record maximum yield parameters in cultivation of taro.
\end{abstract}

Keywords: Plant growth regulators, yield attributes, colocasia, corm, cormels

\section{Introduction}

Among the tuber crop produced, colocasia [Colocasia esculenta var. antiquorum (L.) schott.], a member of family Araceae which is native to south central Asia is one of the important tuber crop particularly grown in Africa and Asia and occupies a very selective and special position. Some species are widely cultivated and naturalized in other tropical and subtropical regions. It is grown throughout the humid tropics and in the warmer regions of the temperate zones. Colocasia is the most important vegetable crop among the arum family due to its delicious taste, nutritive and medicinal value (Mishra and Roy Chowdhury, 1996) ${ }^{[13]}$. It is mainly cultivated for the edible cormels but the leaves and its young petioles are also cooked and used like spinach. The cormels, corms, leaves and petioles are used as a vegetable and considered as rich source of carbohydrates, proteins, minerals and vitamins. The corm is rich in starch and contains 17- 25\% amylase. Planting of Colocasia esculenta is normally done during the rainy season but it can be done any time if irrigation facilities are available. The crop is harvested after 6 to 8 months of planting. It grows on all kinds of soil but thrives best in deep, welldrained, well manured, friable loam. Where rainfall is insufficient, the fields are frequently irrigated.

Moreover, the climate of Jharkhand is very favourable for the growth, development and expansion of this crop. Muktakeshi variety of taro has performed well in eastern and southern part of our country including Jharkhand. It is light brown skin coloured high yielding and itching free choicest variety of farmers of state of Jharkhand. Taro is an promising tuber crop for the state of Jharkhand. It can be found in most of the farmers field of Jharkhand on small holding for domestic consumption or as commercial crop. 
Growth and yield of plants are greatly influenced by a wide range of factors, among which plant growth regulators are one. Plant growth regulators usually are defined as organic compounds, other than nutrients which in small concentration influence the physiological processes of plants.

Foliar application of plant growth regulators is reported to improve growth and tuber yield.

Plant growth regulators are also reported to improve yield of many horticultural crops those in which the underground part is economically important. Though, agronomical practices for taro has been standardized and there is always demand for enhancing its growth and yield from the growers. Hence, the present investigation has been formulated to find out feasibility of increment in yield of parameters of taro by means of applications of growth regulators in the date most accepted variety of taro, Muktakeshi by the growers in the state of Jharkhand. Hence, present study was undertaken with the objectives to evaluate growth and yield of taro with application of different plant growth regulators in the context of growth, yield and yield attributes.

\section{Materials and Methods}

The present investigation entitled "Effect of plant growth regulators on growth and yield of Colocasia [Colocasia esculenta var. antiquorum (L.) schott.]," was conducted in the experimental field of the

Department of Horticulture, Faculty of Agriculture, Birsa Agricultural University, Kanke, Ranchi during the Kharif season of 2017.

There were eleven treatments used namely $T_{1}$ - Naphthalene acetic acid (25 ppm), $\mathrm{T}_{2}$ - Naphthalene Acetic Acid (50 ppm), $\mathrm{T}_{3}$ - Indole Acetic Acid (25 ppm), $\mathrm{T}_{4}$ - Indole Acetic Acid (50 ppm), $\mathrm{T}_{5}$ - Maleic Hydrazide (50 ppm), $\mathrm{T}_{6}$ - Maleic Hydrazide (100 ppm), $\mathrm{T}_{7^{-}}$Gibberellic Acid (100 ppm), $\mathrm{T}_{8^{-}}$Gibberellic Acid (200 ppm), T9- Ethrel (75 ppm), $\mathrm{T}_{10^{-}}$Ethrel $(150 \mathrm{ppm})$ and $\mathrm{T}_{11^{-}}$Control (water spray only) which was carried out in Randomised Block Design with three replications.

\section{Results and Discussion}

The data presented in table 1 shows that maximum Average No. of cormels/plant,

Length of cormel and girth of cormel was observed in $\mathrm{T}_{8}$ $\left[\mathrm{GA}_{3}(100 \mathrm{ppm})\right](17.51,7.94 \mathrm{~cm} \& 11.45 \mathrm{~cm}$ respectively) followed by treatment $\mathrm{T}_{7}\left[\mathrm{GA}_{3}(200 \mathrm{ppm})\right](15.98,6.69 \&$ $10.68 \mathrm{~cm}$ ) in comparison on to others treatments including control (only water spray).

Table 1: Effect of Plant growth regulators on Number of cormels/plant, Length of cormel and Girth of cormel of taro

\begin{tabular}{|c|c|c|c|}
\hline Treatments & No. of cormels/ plant & Length of cormel (cm) & Girth of cormel (cm) \\
\hline $\mathrm{T}_{1}$-Naphthalene Acetic Acid (25 ppm) & 15.13 & 5.52 & 9.96 \\
\hline $\mathrm{T}_{2}$-Naphthalene Acetic Acid (50 ppm) & 13.94 & 4.94 & 9.18 \\
\hline $\mathrm{T}_{3}$-Indole Acetic Acid (25 ppm) & 15.64 & 5.83 & 10.41 \\
\hline $\mathrm{T}_{4}$-Indole Acetic Acid (50 ppm) & 14.79 & 5.14 & 9.68 \\
\hline $\mathrm{T}_{5}$-Maleic Hydrazide (50 ppm) & 12.07 & 4.03 & 7.72 \\
\hline $\mathrm{T}_{6}$-Maleic Hydrazide (100 ppm) & 11.39 & 3.79 & 10.68 \\
\hline $\mathrm{T}_{7}$-Gibberellic Acid (100 ppm) & 15.98 & 6.69 & 11.45 \\
\hline $\mathrm{T}_{8}$-Gibberellic Acid (100 ppm) & 17.51 & 7.94 & 8.96 \\
\hline $\mathrm{T}_{9}$-Ethrel (75 ppm) & 13.43 & 4.64 & 8.50 \\
\hline $\mathrm{T}_{10}$-Ethrel (150 ppm) & 12.58 & 4.30 & 7.69 \\
\hline $\mathrm{T}_{11}$-Control (Only spray) & 10.54 & 3.34 & 0.69 \\
\hline SEm \pm & 1.09 & 0.39 & 2.03 \\
\hline CD (p=0.05) & 3.21 & 1.15 & 12.78 \\
\hline CV (\%) & 13.54 & 13.21 & \\
\hline
\end{tabular}

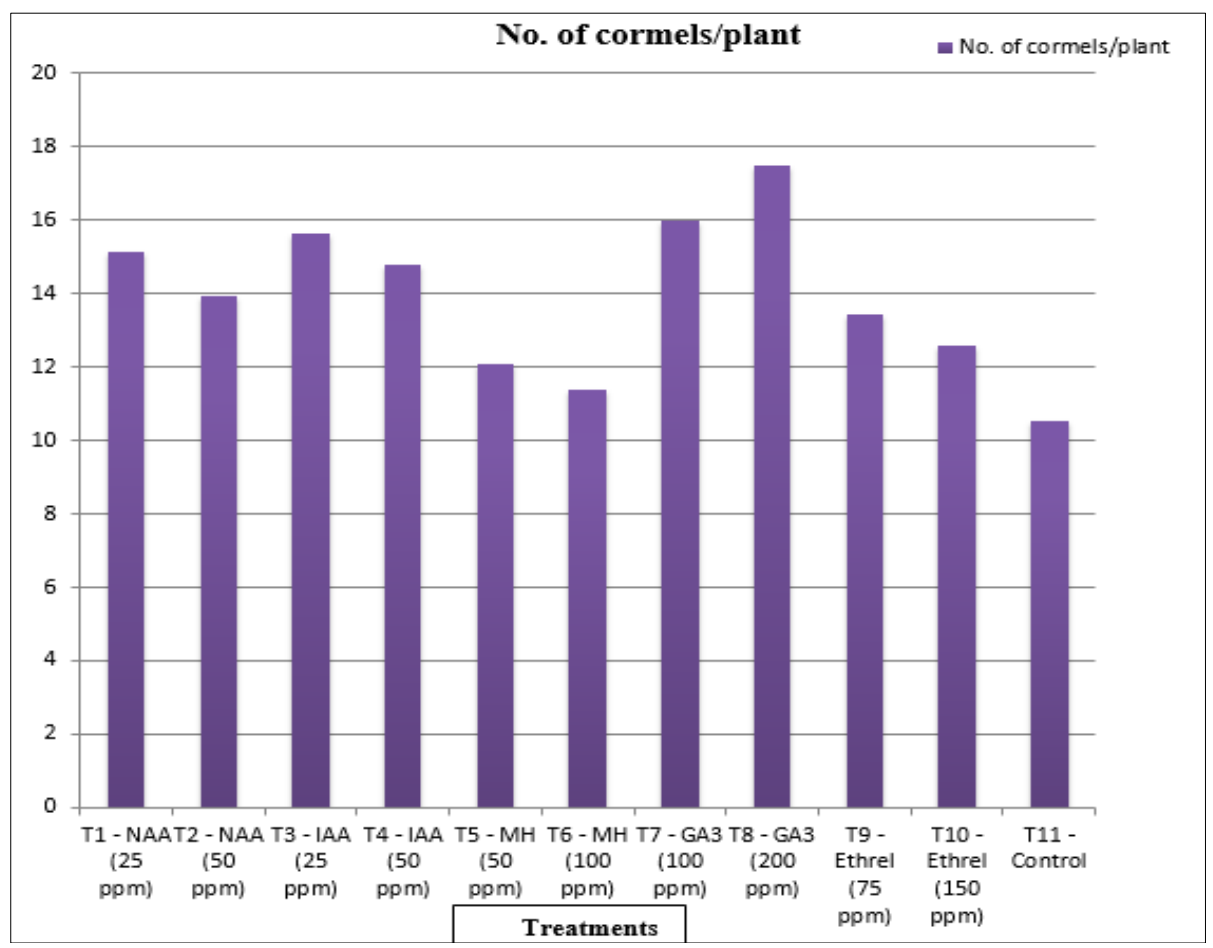

Fig 1: Effect of plant growth regulators on number of cormels/plant of Colocasia (Taro) 


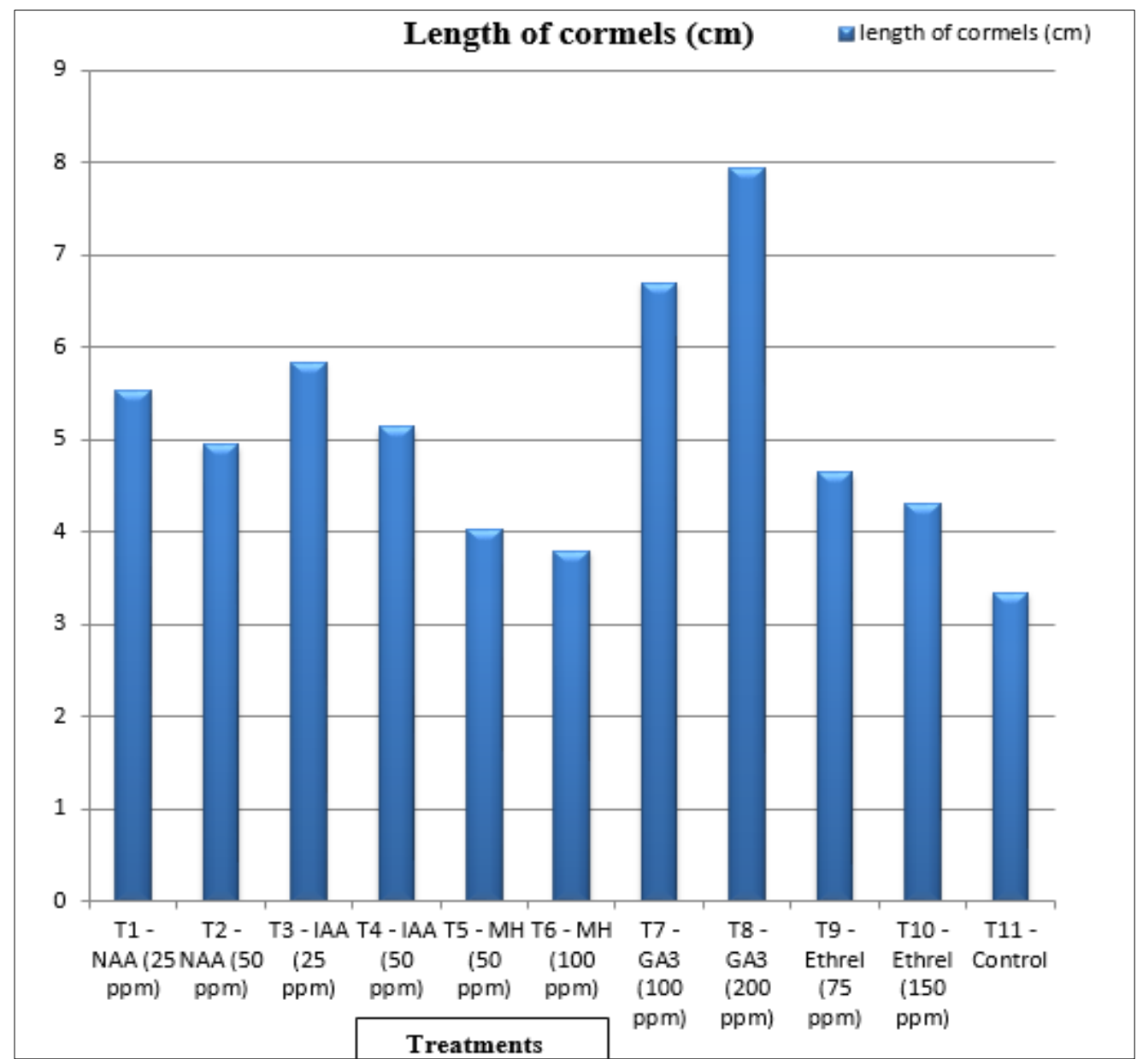

Fig 2: Effect of plant growth regulators on length of cormel $(\mathrm{cm})$ of Colocasia (Taro)

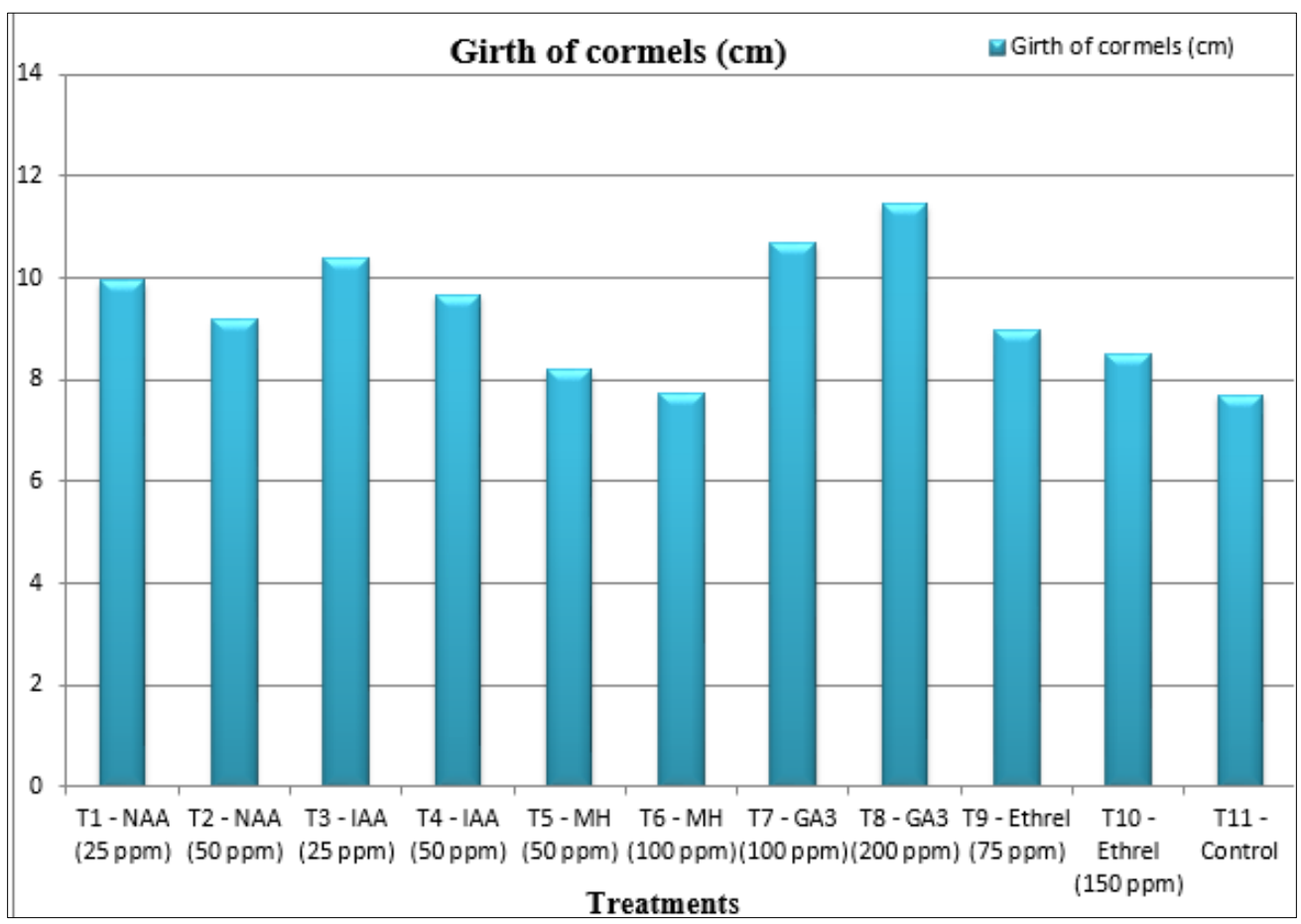

Fig 3: Effect of plant growth regulators on girth of cormel of Colocasia (Taro)

The increase in number of cormel might be due to enhanced photosynthetic activities and efficiency and rapid metabolic processes thereby increase in photosynthates pool and energy which along with increased cell division and elongation processes resulted to force the plant to produce more number of branches. Similar findings with respect to number of branches were also reported by Poudel (2006) ${ }^{[15]}$, Khan et al. (2007) ${ }^{[9]}$, Sarada et al. (2008) ${ }^{[17]}$ and Singh (2010) ${ }^{[21]}$.

The increase in length of cormel might be due to increase in meristematic activity of the apical tissue on $\mathrm{GA}_{3}$ application. Also $\mathrm{GA}_{3}$ was involved in increasing photosynthetic activity, efficient translocation and utilization of photosynthates 
causing rapid cell division, cell elongation and cell differentiation at growing region of the plant leaves leading to stimulation of growth. Similar findings were observed by Kadiri et al. (1996) ${ }^{[7]}$, Iqbal et al. (2001) ${ }^{[5]}$, Poudel (2006) ${ }^{[15]}$, Sharma (2006) ${ }^{[19]}$, Kumar et al. (2008) ${ }^{[10]}$, Sengupta et al. (2008) [18], Sarada et al. (2008) [17], Ud-Deen (2009) [24], Kumar et al. (2011) ${ }^{[12]}$, Sitapara et al. (2011) ${ }^{[23]}$, Rohamare et al. (2013) ${ }^{[16]}$, Chaudhary et al. (2013) ${ }^{[2]}$, Thapa et al. (2014), Chaurasiya et al. (2014) ${ }^{[3]}$, Netam and Sharma (2014) ${ }^{[14]}$ and
Kumar et al. (2014) ${ }^{[11]}$.

Increased in the Girth of cormel is due to crucial role of $\mathrm{GA}_{3}$ in cell enlargement and cell division, increase in the intercellular space in peripheral cells of the cormel and higher translocation of photo-assimilates \& mineral nutrients from vegetative parts towards the developing tuber that are extremely active metabolic sink. The results were similar to the trend found by Kaddour et al. (2006) ${ }^{[6]}$, Sud (2008), Chowdhury et al. (2009) and Thapa et al. (2013) ${ }^{[23]}$

Table 2: Effect of Plant growth regulators on Length of mother corm, Girth of mother corm and yield/ha (tonnes) of taro

\begin{tabular}{|c|c|c|c|}
\hline $\begin{array}{c}\text { Treatments } \\
\end{array}$ & Length of mother corm & Girth of mother corm & Yield/ha (tonnes) \\
\hline $\mathrm{T}_{1}$-Naphthalene Acetic Acid (25 ppm) & 5.80 & 11.44 & 13.45 \\
\hline $\mathrm{T}_{2}$-Naphthalene Acetic Acid (50 ppm) & 5.58 & 10.88 & 12.68 \\
\hline $\mathrm{T}_{3}$-Indole Acetic Acid $(25 \mathrm{ppm})$ & 6.42 & 12.06 & 14.16 \\
\hline $\mathrm{T}_{4}$-Indole Acetic Acid (50 ppm) & 5.72 & 11.26 & 13.05 \\
\hline $\mathrm{T}_{5}$-Maleic Hydrazide $(50 \mathrm{ppm})$ & 4.80 & 10.04 & 11.48 \\
\hline $\mathrm{T}_{6}$-Maleic Hydrazide (100 ppm) & 4.38 & 9.59 & 11.12 \\
\hline 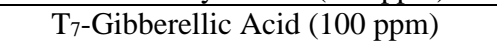 & 6.78 & 12.61 & 14.52 \\
\hline $\mathrm{T}_{8}$-Gibberellic Acid (100 ppm) & 7.64 & 13.43 & 15.38 \\
\hline $\mathrm{T}_{9}$-Ethrel $(75 \mathrm{ppm})$ & 5.31 & 10.69 & 12.64 \\
\hline $\mathrm{T}_{10}$-Ethrel $(150 \mathrm{ppm})$ & 5.12 & 10.28 & 11.86 \\
\hline $\mathrm{T}_{11-}$ Control (Only spray) & 4.14 & 8.76 & 11.26 \\
\hline S.Em \pm & 0.47 & 0.86 & 1.03 \\
\hline $\mathrm{CD}(\mathrm{p}=0.05)$ & 1.38 & 2.54 & 3.03 \\
\hline CV (\%) & 14.43 & 13.54 & 13.8 \\
\hline
\end{tabular}

The data presented in table 2 shows that maximum Length of mother corm, girth of mother corm and yield/ha (tonnes) was observed in $\mathrm{T}_{8}\left[\mathrm{GA}_{3}(100 \mathrm{ppm})\right](7.64 \mathrm{~cm}, 13.43 \mathrm{~cm} \& 15.38$ tonnes respectively) followed by treatment $\mathrm{T}_{7}\left[\mathrm{GA}_{3}(200\right.$ ppm)] $(6.78 \mathrm{~cm}, 12.61 \mathrm{~cm} \& 14.52$ tonnes $)$ in comparison to others treatments including control (only water spray).

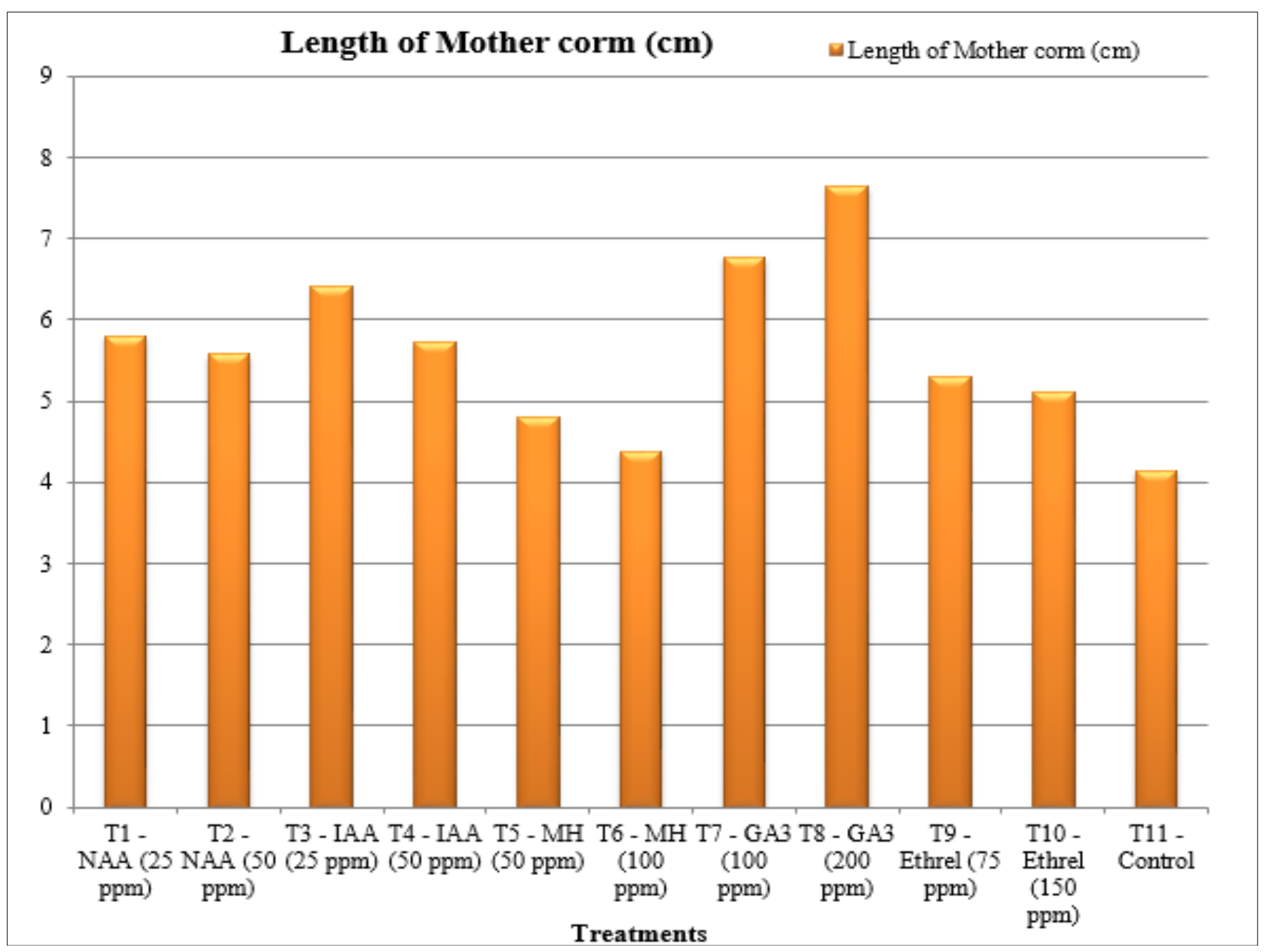

Fig 4: Effect of plant growth regulators on length of mother corm $(\mathrm{cm})$ of colocasia (Taro) 


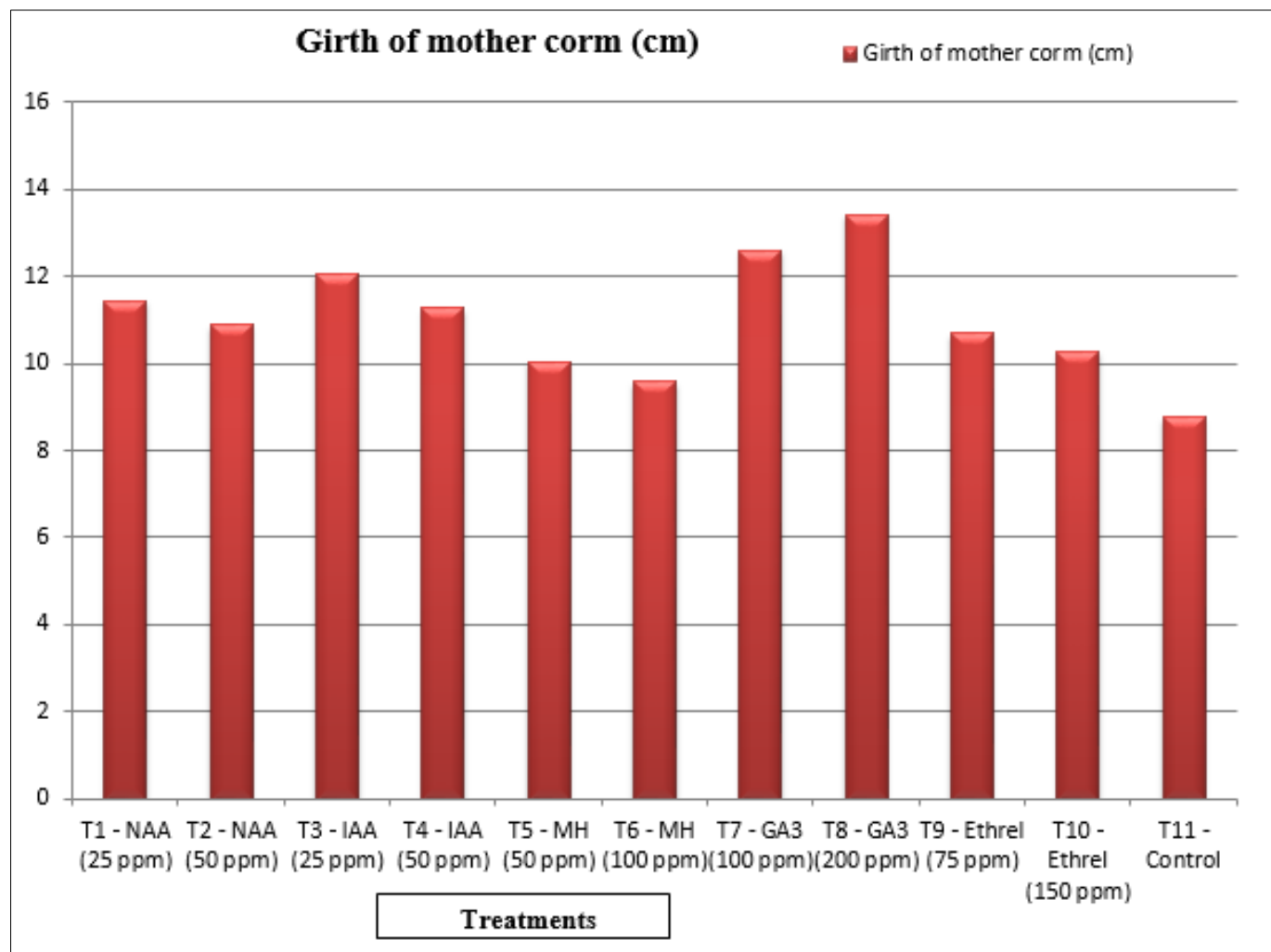

Fig 5: Effect of plant growth regulators on girth of mother corm $(\mathrm{cm})$ of colocasia (Taro)

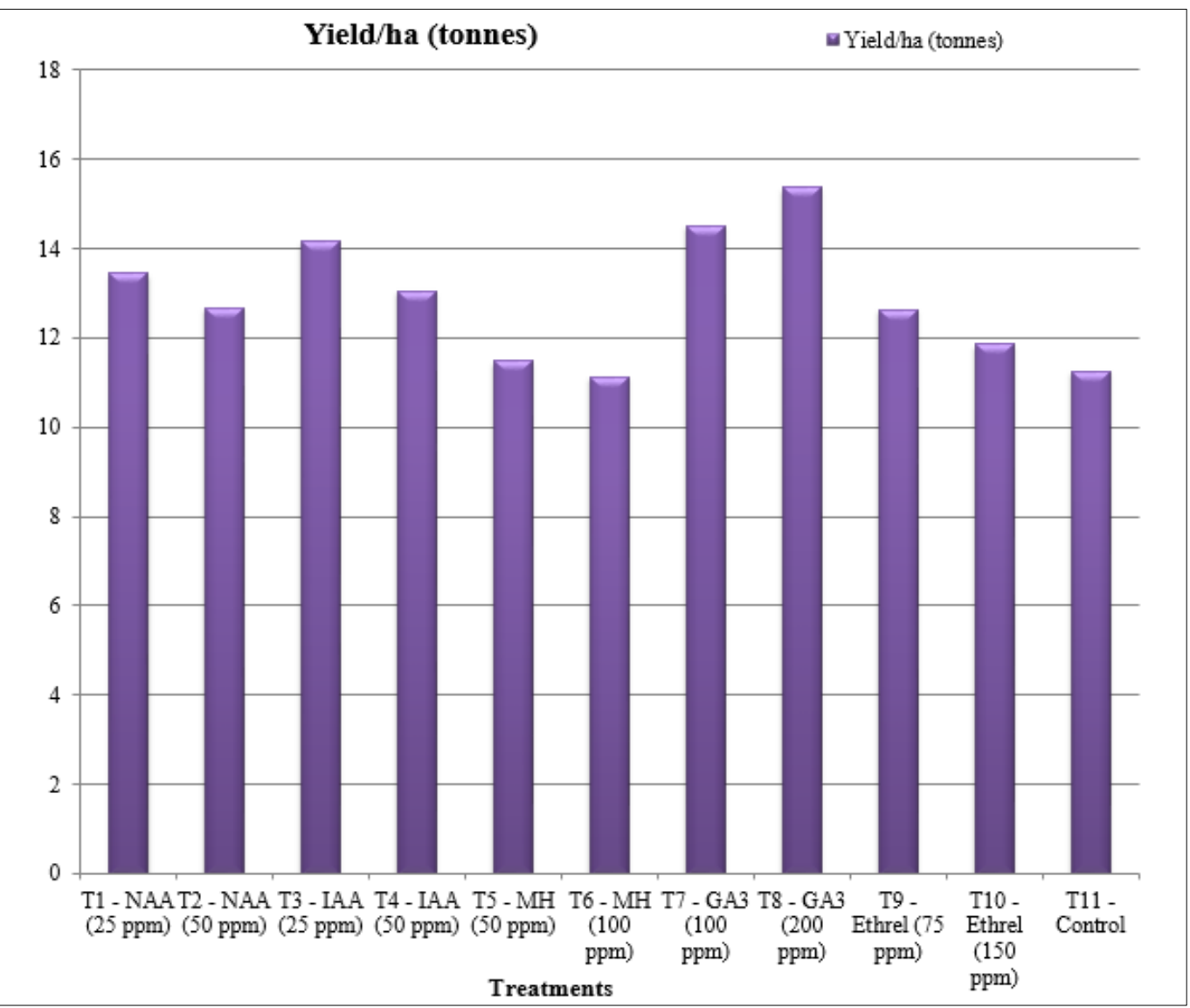

Fig 6: Effect of plant growth regulators on Yield per hectare (tonnes) of colocasia (Taro)

The increase in the yield probably due to the stimulatory effect of the $\mathrm{GA}_{3}$ which prolonged the stomatal openings and induces the large no. of reproductive sinks leading to the greater activity of RuBP enzyme resulting in higher photosynthetic rates with greater translocation and accumulation of metabolites in the sink. The results of yield of tubers are in consonance to that of Shivakumar et al. $(2002)^{[20]}$, Khan et al. (2006), Sharma (2006) ${ }^{[19]}$, Sarada et al. (2008) ${ }^{[17]}$, Birbal et al. (2009) ${ }^{[1]}$, Verma et al. (2009) ${ }^{[25],}$ Farhan et al. (2010) ${ }^{[4]}$, Singh (2010) ${ }^{[21]}$, Kumar et al. (2011) [12], Perveen et al. (2014), Thapa et al. (2014) and Khan et al. (2014). 


\section{Conclusion}

Thus, on the basis of results obtained in one year investigation (2017-18), it can be concluded that foliar spray of plant growth regulators increases the yield and yield attributes. The present investigation revealed that the effective concentration of undertaken plant growth regulators can be used to improve the yield of taro especially treatment with $\mathrm{GA}_{3} @ 200$ ppm \& $\mathrm{GA}_{3} @ 100$ ppm. Considering these parameters, it is inferred that $\mathrm{GA}_{3}$ at $200 \mathrm{ppm}$ can be administered with a view for getting maximum net returns in cultivation of taro.

\section{References}

1. Birbal W, Singh RK, Kumar V, Kushwah VS. Effect of foliar application of plant growth regulators on growth, yield and post harvest losses of potato (Solanum tuberosum) Indian J of Agric. Sci 2009, 79(9).

2. Chaudhury S, Islam N, Sarkar MD, Ali MA. Growth and yield of summer tomato as influenced by plant growth regulator. Intl. J Sustain. Agric 2013;5(1):25-28.

3. Chaurasiya J, Meena ML, Singh HD, Adarsh A, Mishra PK. Effect of $\mathrm{GA}_{3}$ and NAA on growth and yield of cabbage (Brassica oleracea var. capitata L.) cv. Pride of India, The Bioscan 2014;9(3):1139-1141.

4. Farhan HN, Sagar NG, Oxley ERB. Non-destructive and precise studies of the growth of individual potato tubers (Solanum tuberosum L.) under field conditions. Agric. Biol. J. N. Am 2010;1(3):296-306.

5. Iqbal HF, Tahir A, Khalid MN, Ul-Haq I, Ahmad AN. Response of chickpea (Cicer arietinum L.) growth towards the foliar application of Gibberellic acid at different growth stages 2001.

6. Kaddour AA, El-Gizawy AM, Abou El-yazied A, Tawfik AA. Effect of gibberellic acid $\left(\mathrm{GA}_{3}\right)$ on enhancing flowering and fruit setting in selected potato cultivars, Annuals Agricultural Sci 2006;51(1):173-189.

7. Kadiri M, Mukhtar F, Agboola DA. Responses of sorne Nigerian vegetables to plant growth regulator treatments. Rev. Biol. Trop 1996-1997;45(1):23-28.

8. Khan AMA, Hashmi N, Moinuddin Dar TA. Change in growth, yield, photosynthetic characteristics, enzyme activities and essential oil production of fennel (Foeniculum vulgare Mill.) under growth regulators treatments, J of Essential Oil Research 2014;26(2):105113.

9. Khan MMA, Khan R, Singh A, Nasser S, Naeeem S, Siddiqui MS et al. Gibberellic Acid and Triacontanol can ameliorate the Opium yield and morphine production in Opium Poppy (Papaver Somniferum L.), Acta. Hortic 2007, 756(8).

10. Kumar PN, Reddy YN, Chandrashekar R. Effect of growth regulators on flowering and corm production in gladiolus. Indian J of Hort 2008;65(1):73-78.

11. Kumar A, Biswas Tarun K, Singh N, Lal EP. Effect of Gibberellic Acid on growth, quality and yield of Tomato (Lycopersicon esculentum Mill.) IOSR J of Agric. and Veterinary Sci 2014;7(7):28-30.

12. Kumar R, Saravanan S, Bakshi P, Srivatava JN. Influence of plant growth regulators on growth, yield and quality of Strawberry (fragaria X Ananassa Duch) Cv. Sweet Charlie, Progressive Hort 2011, 43(2).

13. Misra RS, Roy Chowdhury S. Phytophthora leaf blight of taro: effect on dry matter production. Journal of Root Crops 1996;22:54-57.

14. Netam JL, Sharma R. Efficacy of plant growth regulators on growth characters and yield attributes in brinjal
(Solanum melongena L.) $c v$. Brinjal 3112. IOSR J Agric. And Veterinary Sci 2014;7(7):27-30.

15. Poudel P. Effect of plant growth regulators on yield and yield component of sweet pepper during spring - summer at Kalyanpur, Chitwan, Inst. of Agriculture and Anim. Sci 2006;1(29):57.

16. Rohamare Y, Nikam TD, Dhumal KN. Effect of foliar application of plant growth regulators on growth, yield and essential oil components of Ajwain (Trachyspermum ammi L.). Intl. J Seed Spices 2013;3(2):34-41.

17. Sarada C, Giridhar K, Reddy T, Yellamanda. Effect of bioregulators and their time of application on growth and yield of coriander (Coriandrum sativum) $\mathrm{J}$ of Spices and Aromatic Crops 2008;17(2):183-186.

18. Sengupta DK, Maity TK, Dasgupta B. Effect of growth regulators on Growth and rhizome production of ginger (Zingiber officinale Rosc.) in the hilly region of Darjeeling district. J of Crop and Weed 2008;4(2):10-13.

19. Sharma MD. Effect of plant growth regulators on growth and yield of brinjal at Khajura, Banke J Inst. Agric. Anim. Sci 2006;27:153-156.

20. Shivakumar R, Patnmanaban G, Kalaran MK, Vanagmudi M, Srinivasan PS. Effect of foliar application of growth regulators on biochemical attributes and grain yield in Pearl Millet, Indian J of Plant Physiology 2002, $7(1)$.

21. Singh SP. Response of plant growth regulator on growth and yield of Fenugreek (Trigonella Foenum-Graecum L.), Asian J of Hort 2010;5(1):234.

22. Sitapara HH, Vihol NJ, Patel MJ, Patel JS. Effect of growth regulators and micro nutrient on growth and yield of cauliflower cv. Snowball-16 The Asian J of Hort 2011;6(2):348-351.

23. Thapa U, Das R, Mandal AR, Debanath S. Influence of $\mathrm{GA}_{3}$ and NAA on growth, yield and quality attributing characters of sprouting broccoli (Brassica oleracea L. var. Italica Plenk) Crop Res 2013;46(1, 2 \& 3):192-195.

24. Ud-Deen Md. M. Effect of plant growth regulators on growth and yield of Mukhi Kachu. Bangladesh J Agril Res 2009;34(2):233-238.

25. Verma A, Mallick CP, Sinsinwar YK, Gupta VK. Yield parameters responses in a spreading (cv. M-13) and semispreading (cv. Girnar-2) types of Groundnut to Six growth regulators, American-Eurasian $\mathrm{J}$ of Agricultural and Envi. Sci 2009;6(1):88-91. 